\title{
Rural Land Reforms in Colombia: Policy and Institutional Challenges for the new Administration*
}

Reformas agrarias en Colombia: políticas y desafíos institucionales para la nueva administración

David Fernando Varela Sánchez ${ }^{\text {a }}$

Pontificia Universidad Javeriana, Colombia

df.varelas@javeriana.edu.co

ORCID: http://orcid.org/0000-0002-9147-9808
DOI: https://doi.org/10.11144/Javeriana.vj138.rlrc Redalyc: http://www.redalyc.org/articulo.oa $: \mathrm{id}=82559799012$

Date received: 15 October 2016

Date accepted: 12 December 2018

Date published: 30 May 2019

\begin{abstract}
:
The implementation of the provisions of the Final Peace Accord on land should have furnished an unprecedented opportunity for Colombia to overcome traditional obstacles to the effective enforcement of reforms to secure land tenure, provide access to vulnerable groups and realize the productive potential of the Colombian countryside. However, two years later achievements in this field are minimal. While most of the academic discussions are still focused on the tension between ideological positions about the extent of private property rights, this paper will look into some of the policy and institutional challenges faced by the Administration that took office on August 2018. The lack of a strong land policy and institutional frameworks has limited the impact of the implementation of previous reforms and may also impair the reforms pursued by the new Administration. The challenges remain significant and, as this paper asserts, unless they are properly addressed, the risk of another frustrated reform will remain high.
\end{abstract}

Keywords: Land reform, land formalization, land information, land restitution, rural land, victims and land restitution law.

\section{Resumen:}

La implementación de las disposiciones del Acuerdo Final de Paz sobre tierras debió brindar una oportunidad sin precedentes para que Colombia superara los obstáculos tradicionales a la vigencia efectiva de reformas que aseguren la tenencia de la tierra, faciliten el acceso de grupos vulnerables, y materialicen el potencial productivo del campo colombiano. Sin embargo, dos años después los logros son mínimos; Mientras que la mayor parte de los debates académicos se han centrado en cuestiones ideológicas acerca del alcance de los derechos de propiedad privada, este ensayo aborda algunos desafíos de política e instituciones que enfrenta la Administración que comenzó en Agosto de 2018. La falta de marcos de política e institucionales fuertes ha afectado la ejecución de reformas anteriores, y puede también afectar las reformas propuestas por la nueva Administración. Los desafíos siguen siendo enormes y, como lo sostiene este ensayo, a menos que sean apropiadamente tratados, el riesgo de otra reforma frustrada seguirá siendo alto.

Palabras clave: Información sobre tierras, formalización de tierras, Ley de víctimas y restitución de tierras, restitución de tierras, reforma agraria, tierras rurales.

\section{Introduction}

\section{A. Country economic and social context}

Colombia has sustained solid economic growth over the past fifteen years and remains one of the top performers in the Latin America and the Caribbean (LAC) region. Growth rates reached an average of 4.8 percent during the 2004-2014 period well above the regional average (3.7 percent). Before 2014 growth was supported by favorable external conditions in terms of prices of exported commodities; prudent

Author notes:

${ }^{a}$ Corresponding author. Email: df.varelas@javeriana.edu.co 
macroeconomic management, as well as some advances in structural reforms, also helped overall performance. After that year the country has weathered successfully the external shocks in spite of the fall in oil prices resulted in a terms of trade impact of more than 3 percent of GDP and external demand for non-traditional exports affected by the weak economic performance of regional trading partners. Over the 2015-2017 period, economic growth has relented to an average of 2.3 percent, but it remains stronger than that of regional peers and compares favorably with the average 0.5 percent contraction for LAC as a whole (See Figure 1$){ }^{1}$

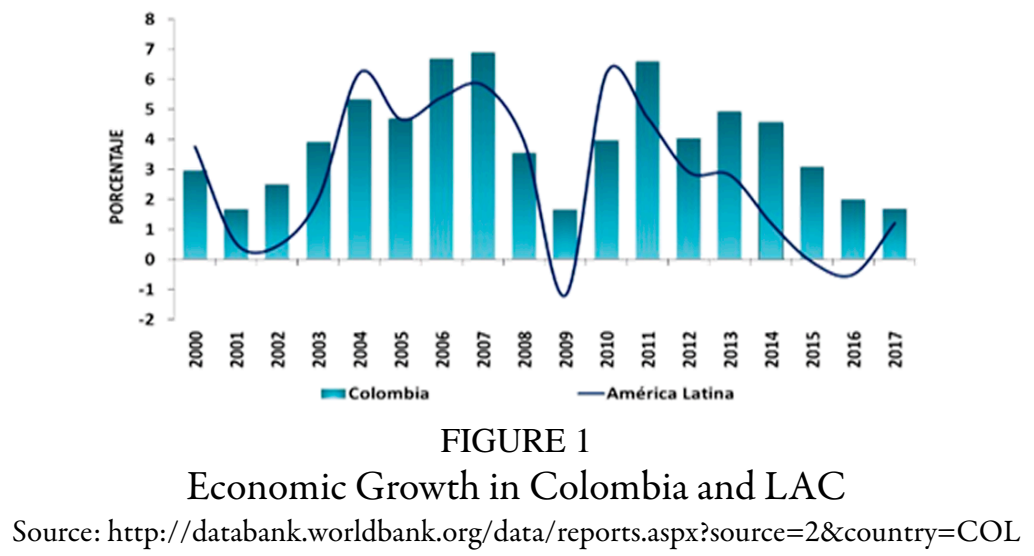

While the agricultural sector currently represents only 6 per cent of Colombia's GDP and 16 per cent of employment, the country's agricultural potential is significantly larger. Over the last 25 years, the growth rate of this sector has been only half the rate of the overall economy. Lack of adequate Government support policies, and poor land use practices have been identified as the main causes of stagnation. Not surprisingly the gains from growth over the past decade have not been equally distributed throughout Colombia as persistent regional gaps remain intractable. Poverty rates vary largely across regions, from as high as 59.3 percent in Chocó and 50.7 percent in Cauca to as low as 8 percent in Santander and 7.3 percent in Cundinamarca, both highly urbanized departments. Extreme poverty in rural areas is over three times as high as in urban areas, and moderate poverty in rural areas is 50 percent higher than in urban areas (See Figure 2). ${ }^{2}$

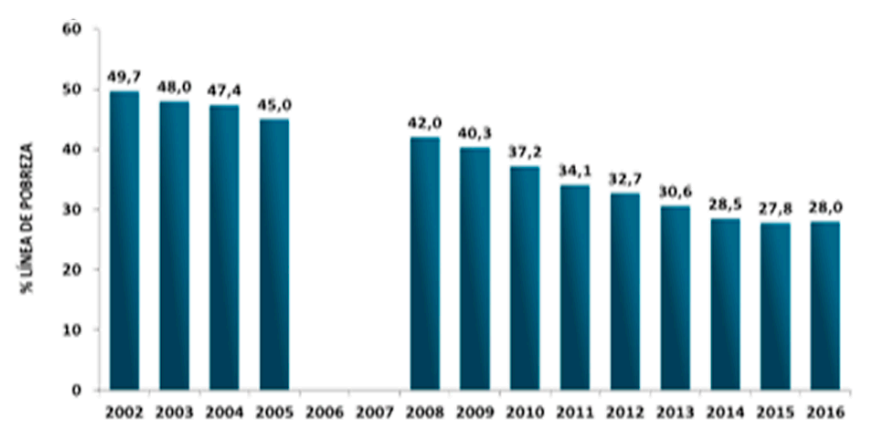

FIGURE 2

Poverty in Colombia

Source: https://www.dane.gov.co

Significant differences persist in access to land and basic services. According to the National Household Survey of 2015, the percentage of households in which at least one member is illiterate is more than three times higher in rural areas than in urban ones; only 21 percent of people living in the countryside has finished middle school. In terms of access to water, in urban areas 97 out of 100 people have access to drinking water, while in rural areas only 74 out of 100 people do. Similar patterns exist with respect to sanitation: in urban areas 85.2 percent of households have access to sanitation services, while in rural areas the figure is only 67.9 percent. Other social development indicators show that gaps in income and living conditions between rural 
and urban areas have continued to widen, for example due to the aging of the rural population, the migration of young people and the increase of female heads of household (See Figure 3). ${ }^{3}$

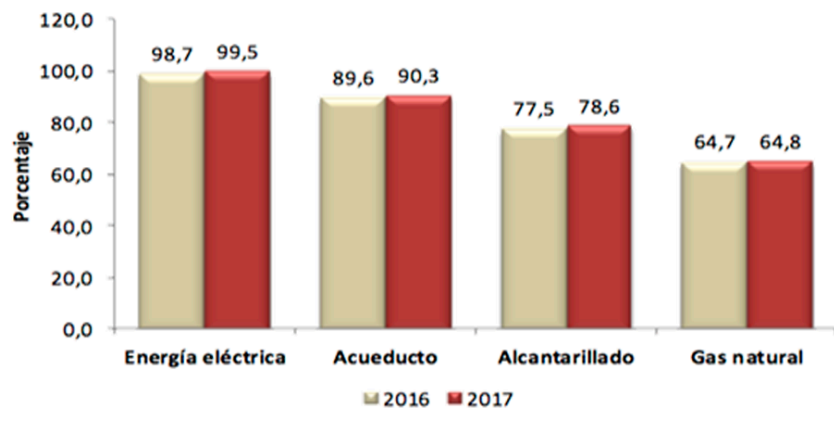

FIGURE 3

Access to Basic Services

Source: DANE (2016-2017)

\section{B. Rural sector context}

Weak social and economic indicators are closely associated with rural land tenure conditions. Only 36 percent of rural households have formal title, and in most cases the area is too small to generate enough income to keep the household out of poverty. 70 percent of agricultural production units consist of smallholder-operated farms covering less than 5 hectares (these units occupy less than 5 percent of the total area) while 0.4 percent of agricultural production units consist of large farms covering more than 500 hectares (these units occupy 40 percent of the total area). Such imbalances have been explained by physical reasons, particularly the uneven topography of the country that naturally isolates certain regions and limits integration in terms of transport and communications (See Figure 4).
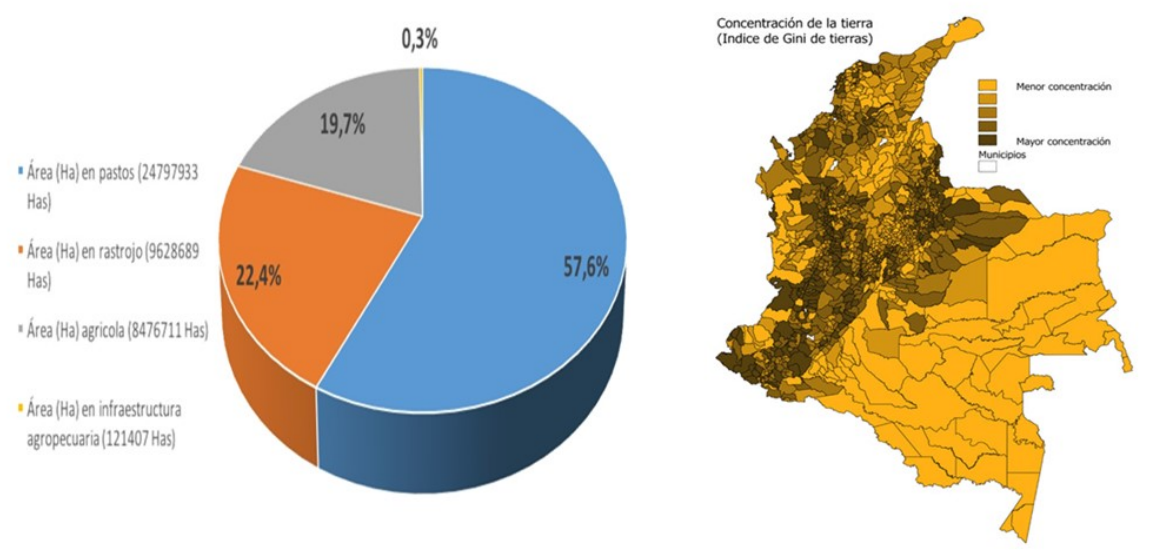

FIGURE 4

Unbalanced land use and ownership

Source: DANE, 2016; Ana María Ibañez, 2017

However, imbalances have been further exacerbated by the armed conflict, which eroded the human and social capital of rural areas, and further weakened government institutions in charge of security and development. Land conflicts reaching back to the start of the 20th century or even before produced a long legacy of insecurity and squatting that had implications for landholding patterns. ${ }^{4}$ Migration of landless peasants to frontier regions resulted in high levels of informal land ownership which also generated opportunities for legal disputes over ownership, and potential for abuse by more powerful economic actors. 
5 Therefore, the worst levels of poverty and economic inequality in rural areas are related to the informal tenure of the most vulnerable groups (particularly, indigenous and Afro-Colombian peoples).

Land inequality and failed reform efforts in the 1960s were behind the formation of insurgent armed groups in the country's periphery. ${ }^{6}$ The conflict pushed millions of people out of their homes and produced one of the largest internally displaced populations (IDPs) in the world (See Figure 5). The growth of illicit crops further complicated the political economy of the conflict. An extremely profitable venture originally fostered by organized crime ended up associated with the financing of insurgent groups, so drug trafficking fueled a vicious circle of impunity and violence in large portions of the Colombian countryside that featured illicit enrichment, capture of local authorities and massive land grabs. Illegal groups took advantage of weak state presence, and co-opted thousands of smallholders into growing illicit crops. The implications of the conflict for land tenure were enormous: an estimated 6.6 million hectares of land were forcibly abandoned between 1980 and 2010, and the traditional land policy and institutional framework proved unable to face the challenges of land reform in front of millions of IDPs. ${ }^{7}$

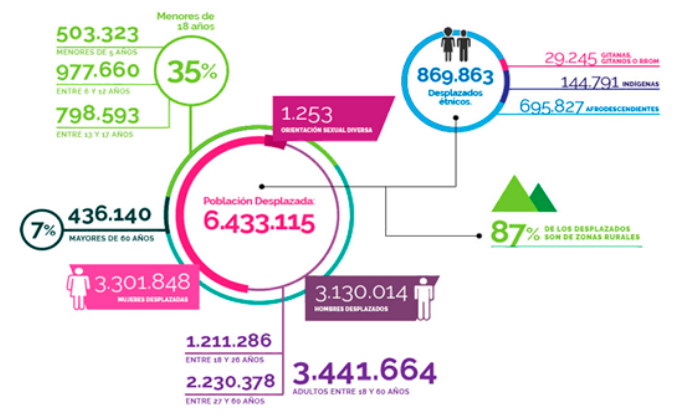

FIGURE 5

Large internally displaced population Source: Centro Nacional de Memoria Histórica

\section{Governance context}

Colombian democracy though still flawed is one of LAC's most stable political systems, ${ }^{8}$ with almost uninterrupted, regularly held, largely free and fair elections according to international standards for the past several decades, and a number of success stories of both judicial autonomy and activism. Nevertheless, the country has suffered one of the longest ongoing armed conflicts in the hemisphere. This paradox may be the outcome of power vacuums of State authority and low-levels of public investment in many areas where not only violence but also corruption became pervasive thereby allowing the vicious cycle of armed conflict with various guerilla/paramilitary groups to devastate the country for over 50 years.

After decades of failed negotiations and attempts to militarily defeat such groups, since the beginning of his first term in 2010 President Santos adopted a new strategy to end the conflict. In 2012, he formally began negotiations with the guerrillas of the Revolutionary Armed Forces of Colombia (Fuerzas Armadas Revolucionarias de Colombia - FARC) and by May 2013 reached a first accord on comprehensive rural development dealing with issues of access and use of land, unproductive lands, property formalization, agricultural productivity and protected areas. Subsequent negotiations during 2014 and 2015 generated consensus on other complex issues such as illegal drugs, political participation and transitional justice. The historic Final Accord to end the conflict, including a cease-fire, handover of weapons and guerrilla member' reintegration into civilian life was signed on November 24, 2016 and was promptly ratified by the Colombian Congress. ${ }^{9}$

The first of the six points in this Accord deal with rural land and development. It calls for improved access to, and better use of, land which would include a massive effort towards land formalization, and the creation and updating of a rural cadaster. The Accord emphasizes the need for an integrated approach to rural 
development through programs to improve productivity, promote access to land, provide technical assistance, and foster regional innovation. Rural land reform was therefore linked to the country's overall development agenda and regarded as critical to consolidate the peace dividend.

The rural cadaster had been pending in the policy agenda for decades. It was unacceptable that after almost 200 years of independent life Colombia had not developed a robust cadastral system to cover the whole country (See Figure 6). In fact, no cadastral records exist for 28 percent of the territory, and where information is available, it is usually outdated. ${ }^{10}$ Cadastral information is not fully systematized, common technical standards for surveying are non-existent, and cartography lacks the required scale for parcel identification, and the planning of infrastructure investments in 59 percent of the Colombian territory. Since cadastral data have traditionally been used solely for tax collection purposes, ${ }^{11}$ information that could be useful for enhancing tenure security and improving land use planning is limited. In small and medium size municipalities, land values are substantially out of date contributing to a lack of revenue from property tax collection. The lack of up-to-date cadaster information not only prevents access to finance, curb productive investment, limit tax revenues, and stifle growth but also the effective enforcement of policies aimed at a more equitable distribution of land, perpetuating inequality and poverty. Even the Government (one of the major landholders in the country) has been unable to enforce its rights on large tracts of State-owned lands.

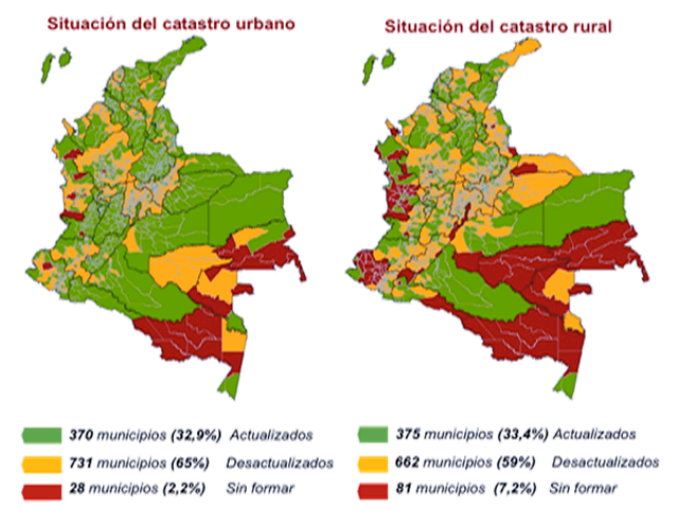

FIGURE 6

Limited Cadastral Information

Source: Departamento Nacional de Planeación - DNP, 2015

In spite of disagreements about the most sensitive political aspects of the Accord, issues related to rural development have remained high during the 2018 Presidential campaign and are expected to stay a priority for following administration. The leading candidates have proposed to increase public and private investment in the rural sector through projects geared to increasing small farmers' productivity, and improving infrastructure and services. While the particular approaches may vary, the candidates have broadly emphasized and integrated approach to rural development, including efficient land use, improved infrastructure, and support to family farming.

\section{Policy framework for rural land in Colombia}

\section{The 2014-2018 National Development Plan}

The 2014 Accord on rural development had set out an ambitious agenda for reforms aimed at reinforcing social and economic changes. The National Development Plan 2014-2018 (Plan Nacional de Desarrollo - PND) ${ }^{12}$ acknowledged that for the benefits of that Accord to be shared fairly, the reduction of territorial disparities in living conditions, and a more educated rural population were essential. The same 
year, the Government convened a Mission for Rural Transformation (Misión Rural) ${ }^{13}$ which delivered a comprehensive set of policy recommendations around six strategies: social inclusion, productive inclusion and family farming, competitive agricultural sector, environmentally sustainable development, territorial planning, and institutional reforms.

The PND provided for a land management and rural transformation policy aimed at increasing access to land for agricultural workers, promoting efficient land use and establishing legal certainty over property rights. The PND expected that the new land use/planning processes would provide the conditions for vulnerable populations to use land to improve their quality of life and socio-economic stability. ${ }^{14}$ More specifically, the PND Enabling Law called for a multipurpose national cadaster, which should unify land information, contribute to the legal security of real property, strengthen local taxation, land use and planning, and overall social and economic development. This multipurpose cadaster should be the basis of a new National Land Management System (Sistema Nacional de Gestión de Tierras - SNGT).

The implementation of PND policies and the establishment of the SNGT should have allowed Colombia to advance the most ambitious land reforms (restitution of land to IDPs, and formalization of rural farmers). For instance, under the proposed multipurpose cadaster, it was expected that the interface between the registry and the cadaster databases would become fully operational to track the dynamics of the land markets in Colombia. Whenever a change in land rights takes place, the databases of both the cadaster and the registry should be automatically updated. To facilitate the search of land information, a single property number would be established for the registry, the cadaster and the new inventory of Government's lands that would have included a full dataset on illegal squatting, good faith occupants and appropriation cases.

The SNGT would have solved the issues related to outdated registration and cadaster databases and interinstitutional coordination through the development of a modern information management system that would: (a) allow the immediate and automatic delivery of the same data to the institutions in charge of the information on real estate transactions between private individuals, and on the property titles; and (b) reduce transaction costs for the lower income population and facilitate access to public registry and cadastral services to all users.

\section{The 2016 Multipurpose Cadaster Policy Paper}

However, progress towards those goals has been notably slow, in spite of the specific guidelines provided by Document No. 3859 of June 13, $2016^{15}$ of the Government's National Council of Economic Policy (Consejo Nacional de Politica Económica y Social-CONPES) about the multi-purpose cadaster. This document includes action plans, tentative budget allocations and institutional arrangements to implement a new multipurpose cadaster. The objectives of the policy were ambitious: (i) to design and implement a system that is complete, up-to-date, reliable, consistent with the property registry, and integrated with other information systems; (ii) to enhance property rights; and (iii) to contribute to fiscal strengthening, strategic planning and territorial development.

Two aspects of the policy statement are highly innovative for Colombia: (i) the cadaster coverage will proceed systematically from area to area across the country (barrido predial); and (ii) the various layers of data collected will provide detailed information on parcels, rights and values that will be critical for economic and social development. Such a fully functional, updated multi-purpose cadaster is expected to yield clear benefits on that side in terms of land use planning, land tenure formalization, municipal property taxation, and investment prioritization. While IGAC still retains the role of policy-making agency on cadasters, CONPES Document No. 3859 mandates sharing that role with DNP and SNR, and empowers municipalities to develop multipurpose cadasters. 
In absence of recent experiences, the National Planning Department (Departamento Nacional de Planeación - DNP) is carrying out 23 multi-purpose cadaster pilots in an equal number of municipalities. The objective of these pilots is to inform the detailed implementation mechanisms that will be rolled out at the national level between 2018 and 2025. The pilots are testing: (i) surveying methodologies and standards for different typologies of land tenure; (ii) implementation mechanisms with significant private sector participation; (iii) information layers to be included in the system; and (iv) efficiency measures to be adopted during the pilot scaling-up phase. At the time of writing, assessment in the performance of these pilots is ongoing.

\section{Institutional framework for rural land in Colombia}

Colombia's legal and institutional framework provides for various forms of private land tenure. In general, individual rights (ownership, possession, squatting and others) are clearly determined and enforced in urban areas, while in rural areas recognition and enforcement is uneven at best. Women's rights are also weak because many women involved in 'common-law' marriages lack of documents to prove ownership of their land. Although collective rights (for indigenous, Afro-Colombian and other communities) are also recognized, major barriers remain for effective enforcement, particularly due to the strong opposition of politically or economically influential actors in certain regions or serious constraints in the organization and representation of these vulnerable groups. ${ }^{16}$

The effective recognition and enforcements of these rights are the responsibility of a number of executive, judicial and autonomous institutions. The complexity of this institutional framework (large number of agencies, potential and conflicting or overlapping mandates, competition for scarce resources, personal and political rivalries among the leadership) may partly explain the limited progress of reform efforts during the last years of the current Administration. ${ }^{17}$

\section{Executive institutions}

\section{Land administration agencies}

Like most countries in LAC region, Colombia has a dual land administration system, in which the physical characteristics of parcels, cadaster maps and geo-information systems are under the responsibility of one institution while information on tenure, ownership and transactions in the property registry belongs to another. Registration of land rights by the Superintendency of Notaries and Registry (Superintendencia de Notariado y Registro - SNR) ${ }^{18}$ is separate from the cadaster surveys under the responsibility of the Geographic Institute Agustín Codazzi (Instituto Geográfico Agustin Codazzi - IGAC). ${ }^{19}$ The cities of Bogota, Cali and Medellin, and the Department of Antioquia have developed their own cadaster agencies.

The information of the registry refers only to the legal status of the property (in alphanumeric format) while that of the cadaster includes only the parcel's physical and economic data (in alphanumeric and graphic formats). The information systems of SNR and IGAC are in general neither fully reliable nor able to communicate thereby increasing the risks and costs of property transactions. Their database interfaces have only operated occasionally as part of special-purpose programs to match cadastral maps/plans with registry records. The out-of-pocket expenses of registering a property transfer (including lawyers and notaries) may reach up to $2-5 \%$ of the commercial value of the land making this process too cumbersome and expensive for most rural citizens, particularly those belonging to vulnerable groups. The overall transaction costs, including time and number of steps of property registration, may be even higher, and the quality and efficiency of 
the land administration in Colombia is only average for LAC standards and low for the Organization of Economic Cooperation and Development (OECD). ${ }^{20}$

\section{Land reform agencies}

In 2015, the Government endorsed institutional reforms recommended by the Misión Rural report and established three new agencies - the National Land Agency (Agencia Nacional de Tierras - ANT), 21 the Rural Development Agency (Agencia de Desarrollo Rural - ADR) ${ }^{22}$ and the Territory Renewal Agency (Agencia de Renovación del Territorio - ART). ${ }^{23}$ The institutional transition was not smooth: the dismantling of the old Colombian Institute of Rural Development (Instituto Colombiano de Desarrollo Rural - INCODER) and the setting up of ANT, ADR and ART posed serious coordination challenges that slowed the implementation of the land reform programs. ${ }^{24}$ The Ministry of Agriculture and Rural Development's (Ministerio de Agricultura y Desarrollo Rural - MARD) is in charge of supervising these new agencies, under a mandate to develop, coordinate and evaluate policies that promote a competitive, equitable and sustainable development of agricultural, forestry, fishery resources, or improve the quality of life of the Colombian rural population. $^{25}$

Once again, the complexity of the institutional setup has not proven conducive for the reforms. Each agency tends to operate in silos paying attention only to the limited scope of its mandate and efforts for broader coordination and alignment with the land administration agencies have been minimal.

\section{Land Restitution 26}

The Victims and Land Restitution Law (Law No. 1448 of 2011) ${ }^{27}$ provides for a mixed administrativejudicial restitution process. The special purpose Unit (Unidad de Restitución de Tierras - URT) ${ }^{28}$ received a fix-term (until 2021) statutory mandate to provide administrative services to victims of involuntary displacement and eviction as a result of the internal conflict after January 1st, 1985. ${ }^{29}$ The URT: (i) administers a Registry of Abandoned Lands (separate from that of SNR) in which victims eligible for restitution and their family households can record claims on the legal status of a land parcel; ${ }^{30}$ and (ii) submits, on behalf of the victims, claims before specialized land courts for land restitution or, where restitution is not possible, for compensation. The Unit may also issue protective measures to avoid the land being sold or otherwise transferred to third parties while the restitution process is underway. ${ }^{31}$ It has developed standard internal protocols for restitution and with a particular focus on gender ${ }^{32}$ and ethnic minority cases. ${ }^{33}$ Complementary programs have also been designed to support social and economic measures for the benefit of individuals and groups of victims.

\section{Land Formalization}

ANT aims at reforming the structure of land ownership through small land awards to poor peasants, smallholders, peasant women heads of household and members of vulnerable groups. Such programs include actions to formalize private property rights, provide clean titles and assist the beneficiaries in complying with the relevant notarial and registration procedures. To that end, this Agency: (i) manages the land of the National Agrarian Fund, monitors property transfers to individuals or communities, and enforces the devolution of State property in the cases provided by law; and (ii) facilitates access to land for small and mid-sized rural producers, and promotes alternatives for efficient, rational and sustainable land use. Its 
regulations on selection of beneficiaries, land transfers and regularization take into account the different levels of complexity of factual and legal issues in various rural areas. ANT's reforms are probably the most challenging item in the land policy agenda because they require gathering enough political will and resources to push forward complex administrative and judicial cases based on the information provided by other institutions.

\section{Other land agencies}

The Colombian Government is one of the main holders of rural and urban lands. The administration of these lands remains under the responsibility of several agencies. Since 2016 ANT is responsible for the public lands (baldios) but a number of other executive agencies deal with particular types of land: (i) the Special Administrative Unit of the National Parks System (Parques Nacionales) with the protected areas; (ii) the Ministry of Environment and Sustainable Development and the Regional Autonomous Corporations (Corporaciones Autónomas Regionales - CARs) are responsible for forest reserves; and (iii) the Ministry of Mines and Energy, the Mining-Energy Planning Unit, the National Mining Agency and the National Hydrocarbons Agency have the responsibility for the subsoil and related resources.

These institutional arrangements have not been particularly successful in preventing the illegal squatting and appropriation of the State lands under the jurisdiction of each agency. It is estimated that more than $60 \%$ of land now considered private has not been legally conveyed and, in theory, has never left the domain of the State. According to SNR, up to 65 fraudulent schemes have taken advantage of an equal number of legal loopholes to facilitate the illegal transfer of State lands.

\section{Judicial institutions}

As note above the debate on administrative vs. judicial land adjudications during the discussion of Law No. 1448 of 2011 was settled through a dual system that mixes both. ${ }^{34}$ That may be a second-best arrangement that takes into account the fact that citizen access to the Colombian court system has always been at issue. ${ }^{35}$ Any individual victim or community can make a direct informal petition to the URT in the administrative phase. The Unit lawyers prepare a case file for restitution that will be submitted to the Land Courts for review and decision. 39 first instance Land Courts (in essence, a group of civil courts temporarily assigned to the resolution of restitution claims) take the final decision based on the information provided by the URT. If there is no third-party claiming ownership over the same piece of land, the judges may issue fast-track rulings granting legal ownership over the land. Cases in which interested parties challenge the claim will move to any of the 15 Land Appeals' Courts. First instance and appeals' land judges have a four-month deadline to rule on individual cases which is seldom met.

\section{Other autonomous institutions at the national and local levels}

Cooperation with other autonomous national and local institutions is sometimes critical for the operation of the land agencies. For instance, URT has to work Personerias, ${ }^{36}$ Family Assistance Units (at the municipal level) and the Ombudsman's Office (Defensoría del Pueblo - DDP) (at the national and local level) to ensure the smooth processing of restitution requests. No official information is available about the effectiveness of these interventions as each institution limits reporting to the number of "users" o "cases" managed instead of focusing on the outcomes. 
Even more complex may be the interaction with regional or local authorities that operate autonomously under the Colombian Constitution. Overall, the capacity of the national agencies to work at the regional and local levels is still being developed, and under the decentralized/deconcentrated administrative model of the country they have to coordinate with the mostly weak departmental and municipal authorities, not always aligned with the higher-level objectives of facilitating access to land for vulnerable groups but sometimes captured by powerful local interest groups. Similarly, these institutional arrangements are not always conducive to addressing the serious bottlenecks for rural productivity the country faces, particularly in terms of infrastructure and services to connect farmers and markets, and technical support for farmers to improve productive practices.

\section{Policy and institutional issues for the new administration ${ }^{37}$}

In addition to Misión Rural, several studies supported by international donors (including the World Bank and USAID) and local think tanks have identified a number of bottlenecks to the effective enforcement of the policy and institutional framework for land in Colombia. ${ }^{38}$ The following review identify the most critical ones that the new administration will have to tackle in order to advance the reform agenda set forth in the Final Peace Accord.

\section{A. Coordination issues}

\section{Re-engineering inter-institutional workflows}

To grasp the complexity of this issue a summary description of a typical workflow may be illustrative: SNR is responsible for recording all land rights in Colombia and, more generally, of providing legal information about land tenure in the country. At the level of departments and municipalities, SNR operates through Regional Directorates and Registry Offices (Oficinas de Registro de Instrumentos Públicos - ORIPs) that have limited autonomy and usually double-check with the central offices before taking major decisions. For the rural sector, SNR provides support to other judicial and administrative agencies in the performance of certain functions, such as protective measures issued by the URT or intermediate/final rulings of the Land Courts and may require the inputs provided by other land agencies such as IGAC to take key decisions about the recording of conveyance deeds. The intricacy of these workflows suggests that the current institutional setup is not conducive to rapid recognition and enforcement of property rights in Colombia but is rather prone to generate frictions among agencies with overlapping functions and responsibilities. If some agencies cannot be merged (as may be most desirable) at least their internal workflows have to be simplified.

Beyond land policies, the broader question of the cohesion of the rural development approaches at the various levels of government remains unanswered. There may be a need to refocus such policies so as to ensure resources are rightly targeted, and the current dispersion of Government priorities is finally substituted by a more consistent policy approach. For instance, the micro-finance programs of the Financial Fund for the Rural Sector (Fondo para el Financiamiento del Sector Agropecuario - FINAGRO) and the Agricultural Bank (Banco Agrario -BA) should be revisited to reach beneficiaries such as the victims that are beneficiaries under the restitution process or informal owners working with ANT. 


\section{Developing multi-disciplinary approaches}

One key challenge for land agencies is the "legal culture" prevailing in Colombia, analogous to that of neverending policy and legislative drafting. For most such agencies it is difficult to think out of the "legal" box, i.e. go beyond the purely legalistic approach to start looking into the social and economic issues involved in land cases. Only gradually some have been able to build interdisciplinary approaches to handle some cases.

For instance, URT has started engaging the land judges for them to understand the constraints of administrative agencies involved in restitution and develop tools to issue more consistent rulings (no common, standardized set of protocols had been followed before, neither a body of case law had been compiled to ensure subsequent rulings were more consistent with precedent). URT has thus worked with the judges to develop 10 guides that unify the criteria for restitution judgments, such as how to deal with gender issues, ethnic groups, collective ownership and secondary occupants. Though not mandatory because the authority of case law in Colombia is still limited this effort may mark the beginning of a significant process of more "harmonious cooperation" between executive and judicial authorities.

Judges and URT staff have also worked to identify bottlenecks in restitution processes and propose practical solutions. As the enforcement of restitution rulings was not standardized either, an additional guide was developed to facilitate such process with the active involvement of the judges. This "enforcement of restitution judgments guide" (rutas de cumplimiento de sentencias) was particularly welcome by the judges as for this critical issue no clear mandates had been previously assigned to local authorities such as the mayors.

The development of joint training programs for agencies such as the Judiciary, the URT and IGAC has also proven useful in developing concerted approaches for typical land information issues in restitution cases (both in the administrative and judicial phases, and up to judgment enforcement). The Judicial School (Escuela Judicial Rodrigo Lara Bonilla - EJRLB) has developed, with IGAC's support, a continuous education program on cadaster guidelines for the Land Judges designed to operate under an innovative legal framework quite different from that usual for other judges. These guidelines were discussed under a case-study methodology (clinicas de casos) that engaged officials of the three institutions in the search of a common approach that ensured consistency, and improved the quality of judicial decisions, as well as in the performance of the administrative functions of URT (file preparation) and IGAC (land valuation).

While promising, these initiatives for a multi-disciplinary approach remain confined to training and technical assistance provided in the context of special-purpose programs such as restitution and have not been extended to other complex land reforms such as formalization where they are also urgently needed. Even more seriously, resource constraints limit the hiring of qualified staff thereby imperiling some changes that require continuous expert input in land agencies. For the long-term, these agencies have to strengthen their own staffs with non-legal expertise (i.e. cadastral engineers for IT investments to be sustainable). Otherwise, the complexity of the land information systems in these institutions may continue to be a challenge for the full integration of cadaster and registry records, a long-term process that cannot be led by consulting firms or individuals but requires the engagement of regular staff with IT expertise. ${ }^{39}$ 


\section{B. Access to secure tenure issues}

\section{Interfaces between the executive and judicial branches}

\section{A. Strategic planning, monitoring and evaluation}

Most land agencies have made limited progress towards a modern planning, monitoring and evaluation based on Key Performance Indicators (KPIs). They continue to use input-based metrics (for example, number of requests or complaints received) instead of output/outcome-based indicators (number of requests responded positively within a standard deadline). For that reason, the comparison or collation of their official reports is difficult as it happens. Only a few executive agencies that have received the support of the international cooperation are evolving towards a more modern system based on KPIs. The Judiciary remains an outlier in terms of very limited and inconsistent reporting.

For instance, a priority objective of URT is to deliver the restitution file required for the judicial phase within the legally established deadline (10 days) which requires a substantial effort vis-à-vis the prevailing 6-month average. Instead of substantial investments on information technology (IT) infrastructure, URT focused on the development of a suitable strategy for automatic exchanges and interoperability that led to the design of the Land Node (see below). URT also prepared a strategic plan on the basis of a more realistic forecast of restitution requests (now it is believed that no more than 170,000 restitution cases will be processed, less than half the number originally envisaged), ${ }^{40}$ and developed guidelines and protocols to improve internal processing performance.

\section{B. Dealing with legal and factual issues}

Land reforms after the Peace Accord face daunting fact-finding and legal analysis challenges. Restitution, for instance, involves protracted administrative and judicial processes around the reconstruction of facts that happened up to more than 30 years ago with the help of scarce surviving evidence. While Law No. 1448 of 2011 alleviated the burden of proof of the victims, and limited the defenses available to current occupants, ${ }^{41}$ URT still has to verify the information provided by the claimants so as to build a strong case that has a chance to pass the test of judicial scrutiny. The outcome of each particular case cannot be easily predicted, and in the interim the high stakes involved may generate conflicting expectations among the affected parties (for instance, between monetary compensation or land restitution), and anxieties related to memories of violent events, or actual violence by occupants or claimants (Martínez Sanabria, 2013). ${ }^{42}$

In spite of its code-level detail the Victims and Land Restitution Law (featuring 208 articles) was not able to anticipate all possible events. For instance, an unexpected issue URT had to deal with was that of "secondary occupants", i.e. cases where the property of the victim of displacement and eviction was occupied by other victim or an innocent third party (neither related to illegal groups) that under a rigid interpretation of Law No. 1448 of 2011 would not be entitled to compensation. However, potentially serious human rights issues were brought to the attention of URT and DDP, and these agencies were able to develop a flexible interpretation of the applicable provisions that was more consistent with the intent of the law and allowed URT to provide various forms of indemnification to the second occupants under the Government's general policies for victims. Once again, the legislative drafting tradition of Colombia (including detailed provisions in major statutes such as Law N. 1448) proved unable to anticipate all possible situations, and the vacuums had to be filled by administrative or judicial decisions. ${ }^{43}$ 


\section{Interfaces within the Executive}

\section{A. Agreeing on joint work programs}

Colombian land agencies have been reluctant to engage in joint work programs. Exceptionally, the priority allocated by the Santos Administration to victim's restitution and land distribution on post-conflict areas helped developing a new culture of inter-institutional cooperation to serve the beneficiaries of a particular program. For example, in the case of certain formalization initiatives ANT has agreed in advance with other institutions a critical path that includes reviews of legal/cadaster information, field visits, demand studies, etc. This common work plan should lead to beneficiaries (including municipalities or departments) receiving clean and marketable title but at all times requires close collaboration among national, regional and local institutions.

Most notably ANT has developed an integrated formalization methodology that requires the provision of cadaster and legal information by IGAC and SNR, respectively. Regional IGAC offices have to visit the field to assist ANT in the formalization process and conduct frequent inter-institutional communications to maintain regular coordination. For particularly complex formalization cases, case-clinics have also been developed with staff of IGAC, SNR, URT and the Judiciary, aimed at establishing appropriate protocols to facilitate inter-institutional consensus-building.

SNR has been one of the agencies most willing to work with others. It has established a special purpose unit in charge of restitution and formalization with responsibilities on cadaster matters. This unit is working on a land inventory to enforce a ruling of the Constitutional Court (No. 488 of 2014) that requires the review of approximately 43,000 files. A pilot for the digitalization and database structuring of these files at the central level is underway as a long-term effort that after substantial time and resources should finish with the allocation of a "land number" (folio the matricula inmobiliaria) to Government land parcels. Under this program, digital records have proven not only more suitable for safekeeping than the traditional paper records, but for the first time SNR has been able to ensure proper follow up of a judicial ruling. While the progress of digitalization is still limited (only around 10 percent of the intended target as of mid-2017) this pilot represents a major breakthrough for SNR's information systems that used to operate under the traditional paper-based model of the current Registry Information System (SIR) dependent on magnetic media.

\section{B. Maintaining a regional focus}

Regional emphasis on land reforms has varied according to agency leadership preferences. For example, some Regional Directorates of SNR have worked closely with mayors and beneficiary communities in the development and implementation of formalization pilots. ANT is leading pilot massive formalization initiatives (barrido predial) in two municipalities ${ }^{44}$ typically starting with schools and health centers that belong to the local government but expected to cover some peri-urban communities. In other regions, ANT is working only on the formalization of public goods (for instance, rural schools for the Departmental Secretariats of Education).

The Local Land Offices established under the ANT pilots are expected to reach specific targets of individual land titles formalized, and to develop a multipurpose cadaster. It is not clear at the time of writing the sustainability of these Land Offices (still financed by foreign donors) and to what extent the formalization targets have taken into account the different conditions of each municipality. While one has been able to formalize individual titles, the other remains focused on formalizing municipal property claiming that the high registry costs cannot be afforded by the municipality for the benefit of individual owners. 
While these small formalization pilots may be successful, major challenges remain for the mid-to-long term formalization process as a whole since Colombia still needs a massive program that fully integrates the registry and cadaster across the national territory. The pilots may provide the building blocks but should be rapidly followed-up with a more comprehensive initiative before the risk of backtracking materializes particularly in the context of a transition to a new administration that will generate additional expectations among the population.

\section{Engaging reluctant beneficiaries}

In the areas where vulnerable individuals and their families become beneficiaries of land reform programs, the recognition of property rights should generate a new government-citizen relationship in which individuals should pay fair taxes and the authorities should account for the use of those financial resources to serve the needs of the communities. Most formalization initiatives (either financed by foreign donors or the Government's own resources) try to address a common land tenure issue in Colombia: as a result of marriages/ inheritance or previous collective titling, large parcels have to be formally subdivided in order to issue individual titles in accordance with de facto distribution arrangements already agreed upon by family or community members. ${ }^{45}$ Nevertheless, not all potential beneficiaries are equally interested in assuming a taxpayer condition they are not accustomed to. Cultural change activities around a new "social contract" in which private owners have rights and duties vis-à-vis State authorities should complement any land reform initiative and overcome a deeply-rooted mistrust of these authorities in large portions of the Colombian countryside.

Women also need preferential treatment to ensure they had access to land titles and become beneficiaries of Government subsidy programs. Basic knowledge about women's land tenure rights and how to ensure proper recognition and enforcement through the Government's institutional processes is critical to make the operators of restitution/formalization processes more sensitive to gender issues. ${ }^{46}$ Land reforms should emphasize engaging community leaders, and working with rural families as main target beneficiaries, to raise awareness about the benefits of empowering women (all family members, including young men and senior adults have to be targeted). Similarly, native/afro-Colombian groups may need guidance and support to go through restitution/formalization procedures. In some cases, indigenous organizations also need help to obtain Government recognition.

\section{Information issues}

\section{Breaking internal silos}

URT (in charge of the administrative phase of restitution), ANT (responsible for formalization of Government-owned land), IGAC (a leading institution on cartography and cadaster rules), SNR (responsible for land rights recording), and the Judiciary (in charge of the final restitution/formalization decisions) have to coordinate regular exchanges of land information. The central and regional offices of these institutions are currently trying to improve coordination through a process that some agencies described as "bringing the central government to the territories" while effectively aligning local and national policies that may otherwise run at cross-purposes, but progress has been slow and limited.

All land sector agencies in Colombia could achieve substantial efficiency improvements through enhanced information gathering/sharing activities. Some face particular obstacles: SNR will have to overcome the internal silos determined by the regional segmentation of its operations across the country. For instance, 
to better contribute to large formalization/restitution activities, SNR regional units would have to work together with staff of other land agencies in the review the background of typical informal land tenure issues, identify eviction patterns and record protection measures. Only by mainstreaming such a coordinated approach on information sharing it would be possible for SNR to provide non-repetition assurances to restitution beneficiaries.

Moreover, investments in land information systems will only be sustainable if the cooperation channels among agencies such as ANT, SNR and IGAC improve. For instance, to preserve records and databases, only SNR has established a Document Management Unit: should the other agencies replicate that model or rather enter into an inter-institutional agreement/understanding for SNR's unit to serve the needs of all? As for the cooperation channels, in addition to regular follow-up with other agencies, SNR has considered engaging the support of independent third-parties that provide feedback on the compliance with the agreed protocols and timetables within the framework of the inter-institutional agreements and understandings entered into with such agencies.

\section{Adopting change management strategies}

To improve inter-institutional coordination/integration around land information, ANT and URT will have to work together with IGAC and SNR in activities such as the development of the Land Node (see below), and common standards for a multi-purpose cadaster. For these initiatives to be fully successful, the traditional silo mentality of some institutions would have to be overcome through a change management process that emphasizes recognition of institutional roles and responsibilities, and periodic contacts among representatives of the institutions to resolve differences or develop a common approach to the issues. ${ }^{47}$ Similarly, change management support may be required to ensure the constructive engagement of rank-andfile employees, and prevent fears about job losses in case automated systems become operational. For example, by explaining that the Land Node or the multi-purpose cadaster will not kill jobs but rather release the time of current employees to more productive tasks.

In the long-term, addressing the key issues of land reform may be impossible in absence of a solid land information system like the one CONPES Document No. 3859 purports to develop. In spite of the fact that some of the multipurpose cadaster pilots envisaged by that Document are still ongoing, the main hope at the time of writing is that the joint World Bank-IDB lending operation will provide the final push for the mainstreaming of long-delayed integrated solution. ${ }^{48}$

\section{Updating internal data management processes}

Document management is essential to ensure effective data collection otherwise weak filing/archiving practices may taint the whole restitution/formalization processes. ${ }^{49}$ Similarly, close coordination between field teams and regional offices of agencies such as IGAC or SNR is required to ensure effective information management by applying data validation methods and quality controls. As INCODER was a highly decentralized institution most of the information systems developed by its regional offices were not standardized or compatible. Digitalization of ANT information is critical for these records to be immediately transferred between central and field offices, and vice versa, so that institutional processes could be more efficient. ANT is currently gathering/managing cadaster information and digitalizing up to 2 million land records.

IGAC is adopting national standards on land information management based on international best practices (such as those of Australia and New Zealand, leading countries in this field). IGAC and SNR are also working on the digitalization of land physical/legal information. For instance, IGAC is undertaking 
the conversion of the cadaster information gathered since 1992 from an analog format into a digital one, information that should be usable for the restitution and formalization programs of URT and ANT. In addition to the technical aspects of the conversion IGAC has started a change management processes at the national and regional levels, including awareness-raising among the staff of the various institutions involved and is leading the development of a georeferenced portal supported by a foreign donor. ${ }^{50}$ Nevertheless, to date these operational improvements seem to be still marginal, only at a trial stage, and manual handling of information still prevails. URT has also had to manage the confidentiality of the potentially sensitive information gathered, and the risk of misuse by URT officials or contractors. Strict URT information security policies are required (including details about security profiles to access hardware and email software) to enforce the Colombian statutory provisions on protection of personal data (babeas data).

\section{The Land Node Pilot}

With USAID assistance ANT, SNR and IGAC are developing a Land Node that should further assist with inter-institutional coordination and strengthening around the development of new land information systems. If fully successful, the Land Node will become the first of its kind in Colombia and will show the Government is able to operate IT solutions to interoperability issues beyond institutional silos.

This Node should expedite information exchanges among sector institutions through the development of common interface language/standards. The Node includes the design of an application that will run through the institutional webpages of the participating agencies. This working interface among land institutions should provide better services (lower cost, less time, higher quality) to all users. Substantial synergies are also expected from the successful implementation of the Node by integrating seamlessly the hardware/software platforms of the land institutions.

The Node should also replace the current manual land information exchanges for an automatic system that also generates statistical information about the parties to land transactions (gender, age, socio-economic strata, etc.) and integrates some additional functionalities to ensure efficiency and transparency, such as the victims/beneficiaries ability to check the status of their file. Ideally, as the integration of registries-cadasters makes parallel progress the Land Node should allow all the participating institutions to access a single database of physical and legal information about land parcels identified by a single number.

The Node demands very close coordination among IT managers and appropriate inter-institutional arrangements involving not only inner circle land institutions (such as URT and SNR) but also IGAC and the Judiciary. Coordination among these agencies may be particularly challenging as they are known for zealously defending their own powers. Each agency will have to understand the internal complexities of the others to keep the multilateral process ongoing instead of reverting to the tradition of bilateral exchanges that in the past proved unsuccessful for the decision-making process around the integration of land information systems. For instance, such systems may help making more visible gender issues by including gender-differentiated layers of information like "women heads of household". It is expected that the Node will also facilitate the exchange of that type of information among participating agencies.

The Land Node has faced significant implementation obstacles. A purely technical challenge for the gradual convergence of the land agencies that have started participating in the initiative is the different levels of IT capabilities. While frequent turnover of liaison officials in these agencies had delayed the progress towards key decisions, it was expected that the Land Node would become operational before the end of the Santos Administration. It is not clear how and when the Land Node initiative would be linked with the multipurpose cadaster that the World Bank and the IADB plan to finance, perhaps as an interim stage not as a parallel initiative. 
The Land Node may provide a powerful instrument for the benefit of all the institutions involved in land tenure issues to the extent that it will help them to process and organize data under common standards that should lead in the near future to a fully digitalized system. Nevertheless, it will also be critical to align as early as practicable the investment plans of the major land agencies in a way that duplicated or overlapping of IT systems are not purchased. ${ }^{51}$

\section{Policy options for the land reforms of the new administration}

Land reforms are complex and for many decades have posed heavy burdens on the responsible Government agencies in Colombia. While the legal and regulatory aspects of the reforms have tried (not always successfully) to provide clear rules to deal with critical land issues, the institutional arrangements have never been fully conducive to reach the ambitious goals set out by reformers in Congress or the Executive. The effective implementation of the land provisions of the Peace Accord may be even more challenging. Too many agencies are involved, some with unclear roles (such as the successors of INCODER), while others (such as the notaries and judges, key players in the restitution and formalization processes) have not been fully engaged. The institutional side remains the weakest link of the reform process and may break at any point even the best planned reform efforts. This section presents some policy options about how these institutional challenges can be addressed by the upcoming Colombian administration.

\section{A. Coordination}

\section{Developing new institutional arrangements for decision-making and implementation}

Before adventuring new proposals for policy development or drafting new laws and regulations the Colombian authorities will have to focus on the most suitable inter-institutional arrangements for decisionmaking and implementation. Some of the typical constraints of Government institutions, such as the high staff turnover, or weak expertise in some technical areas (not completely surprising in view of the fact that most of the staff of some Government agencies are short-term contractors) must be overcome in the land sector for the more challenging goals of restitution and formalization to be accomplished. New policies, laws and regulations may fall into a vacuum if no solid institutional arrangements are put in place first.

The new administration will have to consider the possibility of abolishing or merging some agencies in an effort to simplify the institutional setup. While the URT's special-purpose mandate fully justifies its existence until the expiry of the statutory mandate; thereafter, victims issues could be handled by ANT as a particular formalization service. The potential for merging SNR and IGAC into a new Land Administration Agency (as it has happened in other LAC countries) should be explored. DNP may return to its traditional public investment monitoring and evaluation responsibilities. The experience with high-level boards or commissions has proven most become short-lived and ineffectual so more drastic decisions may be required to bring some order into a sector that has not been able to develop consensus around major reform proposals.

\section{Advancing an accountability and decentralization agenda}

A distinction should be made between a mere "administrative" strengthening (i.e. internal processes improved through IT) and the real "institutional" strengthening in which the legitimacy of the institutions vis-à-vis the society at large improves. For this dimension to be properly addressed, Government agencies may have to leave "comfort zones" and move into higher risk activities such as public hearings or town hall 
meetings where they are willing to listen to citizens. By reinvigorating the public trust, the institutions will be able take over a leadership in the implementation of the Peace Accord provision on land tenure at the national and local levels.

Coordination among these various levels of the institutions has to improve substantially for the Final Peace Accord provisions on rural land tenure to be implemented. Increased cooperation among land sector institutions would depend on: (a) consistency in the mandate of various institutions so as to identify and mitigate the risk of duplicating efforts (i.e. either URT's Cadaster Unit or IGAC should double-check land information not both); and (b) faster processing of information exchange requests, especially between the SNR, IGAC and URT, as expected under the Land Node or the multi-purpose cadaster.

Other traditional tensions will have to be smoothed, particularly among some national agencies and the departmental and municipal authorities. Properly implemented, the multi-purpose cadaster model of CONPES Document No. 3859 may also help developing healthy competition among municipalities eager to receive various benefits in terms of taxation, land zoning and planning. ${ }^{52}$ The opening of brand new local offices of national organizations such as ANT is critical for the broader decentralization/deconcentration process to make inroads into the highly-centralized land sector.

\section{Enhancing the multidisciplinary/inter-institutional focus}

The traditional organization of the land sector institutions in specialized groups (mostly staffed by lawyers) may be useful for regular operations of land administration but to support land reform programs the right set of skills is required to go beyond internal silos, preserve policy coherence and prevent compartmentalization. After the Final Peace Accord these reforms will require resource mobilization under even more complex scenarios with new social and political players so matching the pace and focus of each initiative will be difficult for isolated teams within agencies that serve various policy priorities.

Regional managers of each agency will have to connect and integrate the approach to the various land initiatives, and coordinate the work of inter-disciplinary teams with authorities and communities that only look at small portions of the broader rural land picture. The model of the task forces that is common for programs financed by the international cooperation may be streamlined for initiatives such as massive formalization that require the contribution of a number of agencies and professionals with different profiles to achieve a common goal (for instance, to finish cadastral surveys in a single municipality or groups of municipalities within a given timeframe).

\section{Privileging selectivity and continuity}

One special feature of land reform approaches after the Final Peace Accord that this paper wishes to highlight is the need of flexibility to adapt to changing priorities. As the various land reforms (restitution and formalization) continue to move forward, the responsible agencies should be able to identify particular zones within larger geographical areas that are more promising than others in terms of ability to deliver results, and refocus resources and efforts to such zones/areas accordingly. This opportunistic approach is fully consistent with the broad design of CONPES document No. 3859, ${ }^{53}$ and could help developing some success stories that might not happen under more rigid structure, for example, the development of massive formalization methodologies.

A regional focus would be highly desirable given the challenges of the institutional transitions at the central level resulting from the disestablishment of INCODER and the slow start-up process of ANT and should be retained if the new administration decides to effect a radical reorganization of the sector. The traditional practice of suspending regular activities while organizational reshuffles are finalized should be replaced by a 
more pragmatic approach that allows the agencies to continue operating on a "business-as-usual" mode on the ground while the new institutional set-up is finetuned in the center.

\section{Stabilizing the interfaces between administrative and judicial processes}

Unless an "administrative reform" model is adopted at the initiative the new administration, the Judiciary will continue to play a major role in the implementation of land reforms. If that is the case the arrangements developed under the Victims and Land Restitution Law will have to be maintained and strengthened. That experience showed that working only on the administrative side of the restitution process would limit the potential of URT to show even more tangible results. As the administrative file of URT is subject to the review of the Special Land Courts that may find weaknesses in the legal or factual grounds of the decisions taken by URT, it is critical to continue the efforts to develop more consistency in approaches to diminish the risk that different interpretations by the URT and the Courts lead to inconsistent decisions.

While carefully respecting the autonomy of the judges, it is also essential to enhance the mechanisms for engaging the judges and Courts staff in a dialogue about policies. The operation of the Land Node may serve as the basis for that engagement but should be supplemented by activities such as continuous joint training or information exchange programs that have proven effective in generating a better understanding around some legal and technical issues of common interest. The interim arrangement of some circuit judges temporarily assigned to land matters should be replaced by a more stable system of Land Courts where the specialized expertise acquired judges and other judicial staff in the study of land cases can be retained.

\section{B. Access to secure tenure}

\section{Identifying a realistic sequencing for the reforms}

Restitution rightly received priority in the context of a peace process so now, after the Final Peace Accord, continues to stand above formalization reforms. It is also the reform that may show the most visible quantitative results as it is been properly tracked since the inception. However, in the mid-to-long term formalization and the multi-purpose cadaster cannot remain as a complement to restitution, mere supporting activities designed to ensure that the broader issues of the land sector are taken into account. Time and resources may not have been sufficient for them to move as faster or as effectively as it would have been otherwise desirable during the peace process, but those constraints should be addressed by the new administration.

Moreover, it is likely that under that administration the emphasis shifts towards formalization, as the mandate for restitution expires in 2021. A more balanced approach among the various reforms within a broad land policy will be critical. Irrespective of the more pro-business or pro-peasant focus of the candidates for the 2018-2022 Presidential term, both seem committed to improving living conditions on the country side a policy objective that requires addressing poverty and inequality issues connected with land productivity and tenure. Formalization is expected to continue in high demand in the foreseeable future, and the new Government will have to provide the institutional setup to serve that demand.

\section{Transitioning to a massive formalization model}

Protracted formalization processes and unaffordable expenses for vulnerable communities have been identified as one of the major impediments of formalization initiatives in Colombia, and a number of 
other countries in LAC. The outgoing Administration started the transition from the traditional model of formalization "on demand" into a supply-side model that requires more proactivity by the agencies in charge that should stay in place under the incoming one. As noted above, after the negative experiences of INCODER, formalization activities by ANT have started less than one year ago, and it is hard to assess progress to date. The few pilots that have tried massive formalization have shown promising results, but it is critical to move quickly into full-fledged implementation to keep the momentum and retain the technical and professional expertise developed around the pilots.

Stakeholders should be allowed to look into the results of this pilots vis-à-vis the high expectations generated in terms of reducing the titling process time and the cost. Stakeholder support may be critical for the pilots to be follow as early as practicable with a mainstream massive formalization model that covers larger tracts of the country. A Government that is really committed with land reforms should move quickly to show results on the ground to avoid the disappointments that have been common during more than eight decades of highly-publicized reforms efforts that had resulted in meagre land formalization or redistribution.

In rural areas, for individual and collective titles to be properly recorded future reform programs should remove remaining access barriers to registry services particularly in terms of out-of-pocket expenses and other transaction costs, and insufficient awareness by legal owners of the need to formalize land rights with a title recorded in the registry. Simply by facilitating compliance with legal requirements, SNR and the notaries could help vulnerable groups and individuals to ensure that their rights are properly protected by: (A) succession procedures to transfer lands in case of death; (B) registration by the beneficiaries of baldios awards; (C) registration of improvements and possessions; and (D) signing public deeds instead of informal documents to effect the transfer of property rights over land.

\section{Incorporating alternative dispute resolution mechanisms}

While Land Courts involvement cannot be avoided under the current system, reformers should also explore the potential of Alternative Dispute Resolution (ADR) to take cases out of the court system or prevent simple cases from escalating out of control into protracted litigation. ADR may be particularly useful in formalization cases but could only be used in a broader societal setting, beyond the institutions or beneficiary communities directly engaged in formalization, that provides legitimacy to mediation or conciliation techniques as an option to court rulings or administrative agencies' decisions. The complexities of formalization issues may be more rapidly and amicably dealt with by ADR than through an adversarial judicial process that generally ends with winning/loosing parties. Also, the social realities on the ground may be better captured by an ADR process than through the traditional court debate where legal formalities usually take precedence.

Land-related grievances were not only the source of the old conflict, but failure to address them now could further increase the potential for renewed conflict. The risk of land-related conflicts is significant, and ADR might include several mechanisms to reduce/manage conflict in the field, including social mapping ${ }^{54}$ and sensitization of the communities participating, providing legal and technical advice during the process, and a grievance mechanism for those not fully satisfied. While no such system can respond to 100 percent of conflicts, it may be helpful to minimize the potential and respond on the ground. Key vulnerable groups whose land rights require extra attention - women, indigenous peoples and Afro-Colombians - may require specific Government interventions to deal with their specific issues. 


\section{Information}

\section{Enhancing public information/consultation}

The institutions/organizations engaged in land reform should undertake more dissemination work with larger audiences that may not be directly involved in the process but whose support in a given region may be critical (for instance, civil society organizations or academic institutions) particularly to prevent uninformed or misinformed opposition. Wider public information in target areas could explain to citizens and communities the close connection between reforms and sustainable peace, as well as the differences between formalization and restitution.

\section{Generating standardized statistics}

A general issue for the land reform programs as a whole is the use of appropriate metrics. Statistics provided by the agencies involved are not fully consistent. For example, with less than 5 years left some indicators suggest (as noted above) that the number of beneficiaries of URT and the size of the land involved in restitution were overestimated at the inception. Not surprisingly, by mid-2017 only 3,200 restitution rulings and 9,000 protection orders had been issued by the Special Land Courts. The determination of the total cost and the per-parcel cost of restitution and formalization would be also useful to better target the reform programs. The new Administration may wish to ascertain such costs to determine the sustainability of the reforms and explore alternatives to titling.

One promising area is the articulation of the planning instruments of urban and rural land used by the different levels of government, especially in the rural sector where local authorities with responsibilities for land planning should be fully prepared to face the challenges of a modern land management system. In addition to the PND, regional and administrations have to prepare their own departmental and municipal development plans (Planes de Desarrollo Departamental - PDDs or Planes de Desarrollo Municipal - PDMs) within the six first months of taking of office. These plans are supposed set out the social and economic indicators of the local government during a four-year period. In parallel, the POTs should provide the "rulesof-the-game" for land zoning and planning, as well as infrastructure investments, within each jurisdiction but are seldom updated or connected with the development plans. A reform should be considered to link both instruments closely for georeferenced data to be gathered about the progress on the ground of the planned investments while tracking the socioeconomic improvements of the surrounding communities.

Similarly, the cadastral valuations to establish the tax base for the unified property tax in rural areas have to be consistent with physical and market realities. Future reforms should emphasize: (i) conducting periodic cadastral surveys to update relevant information; (ii) gathering and analyzing information on land markets, especially in rural areas; (iii) limiting appraisers' discretion on valuation methodologies; (iv) banning land use decisions that favor particular interests, or facilitate speculation; (v) adopting land distribution policies targeted to vulnerable groups; and (vi) preventing political or economic influences from keeping large landholdings undervalued.

\section{Conclusions}

Land tenure issues in Colombia are complex, and impossible to tackle all at the same time. The existence of a large number of Government land-related institutions has posed significant obstacles for the design and implementation of a single coordinated and consistent reform program, and favor the development 
of separate, isolated initiatives. To resolve Colombia's multifaceted land sector issues, the Government will have to develop a more manageable institutional framework that facilitates the achievement of the ambitious policy objectives of the Final Peace Accord at the national level while focusing on targeted regional implementation of pilot initiatives to help Colombia moving through diverse scenarios on the ground. The above discussion of issues and policy options has identified some priority areas for the new administration that (irrespective of ideological preferences) will have to be addressed to defeat the natural trend of the Colombia bureaucracy to inertia.

\section{A. Coordination priorities}

- Making effective the institutional framework for land management by: (a) a redefinition and/ or simplification of institutional mandates; and (b) avoidance of duplicating, overlapping or contradictory functions and responsibilities among central and decentralized agencies.

- Coordinating programs and projects of various sectors (i.e. agriculture, mining and energy, transport, environment) by generating proper incentives for land allocation/use in accordance with the technical criteria of PDDs, PMDs or POTs, or quick ADR among stakeholders.

\section{B. Access to secured tenure priorities}

- As most cases of non-compliance with legal requirements are associated with the high costs of notaries, registry/cadaster and lawyers for vulnerable individuals and communities who do not have the required resources, especially if the travel/time costs of compliance are added, any future land reform program should provide incentives such as low or no cost for the first registration and affordable costs for subsequent transactions of these groups.

- Protecting areas within forest reserves against encroaching by agricultural and mining uses and provide for effective compensation mechanisms in cases of change in land use.

\section{Information priorities}

- Land reform programs should ensure consistency between the physical and legal description at the time of recording any transaction, in both the registry or the cadaster. Database interfaces between the agencies responsible for either has to become fully operational as a permanent feature of the information technology systems used by all the agencies involved, as proposed under CONPES No. 3859 .

- The legal or geo-referenced information about State lands has to be fully reliable and allow effective enforcement of State rights in the whole national territory. The cadastral and registry records should match variables such as area, boundaries and cartography. Such information has to be compiled into a single standardized repository even if it remains scattered in various agencies so as to make it fully accessible to the public or to other agencies.

- The costs and benefits of implementing land policies have to be properly measured. The figures currently available are only general estimates, and the institutional capacities to conduct more detailed exercises are limited. A standardized country system for monitoring and evaluating the achievement of the social/economic objectives of land policies has to be developed that allows the institutions to report the progress in policy implementation under a single reporting methodology. 


\section{Final remarks}

\section{A. Land Reforms with a productive focus}

The implementation of land reforms will require the Government of Colombia to address serious security challenges such as the presence of armed groups (guerrilla/paramilitary/illegal cartels involved in drug trafficking) or the growing tensions between indigenous and peasant farmers. To address this issue some efforts were made in the final year of the Santos Administration to increase the coordination between the Office of the High Advisor for the Post-Conflict (Alta Consejería para el Posconflicto - ACP), ${ }^{55}$ ANT, IGAC, etc., around ACP plans for crop substitution. This cooperation helped identifying and characterizing particular territories where ACP worked on peace pedagogy, thereby providing this national agency a better reading of land issues and the local context, and insights about how the Peace Accord could be implemented more effectively under heterogeneous settings.

The involvement of ACP also helped identifying in some regions how to promote the reintegration of armed fighters and the reduction of community tensions, two aspects critical for the success of the Accord, particularly where the power gap left by FARC demobilization has increased crime and violence, or the conflicts between indigenous and non-indigenous peasants around land ownership continue to grow. The generation of new economic opportunities may be essential to ensure illegal groups remain demobilized, and farmers are trained to develop productive projects. Otherwise, economically depressed regions may face major difficulties to reintegrate fighters and the results of the proposed land reforms will not materialize.

\section{B. Smooth law-making processes}

In spite of the relatively recent reforms of the institutional framework for the rural land sector, uncertainty exists at the time of writing this essay about the role some agencies will have for the remaining of the Duque Administration. Under the "fast-track" Congressional procedures for the implementation of the Final Peace Accord a bill was drafted by the Santos Government to transfer some of IGAC key functions and responsibilities to DNP. DNP would become the authority responsible for the multi-purpose cadaster implementation, and the delegation of cadaster authority to departmental and municipal governments. SNR would take over monitoring and evaluation roles. IGAC would relinquish its current leading role on cadaster and would be downgraded to that of a "cadaster information administrator". The report for the first reading in the congressional commission introduced what the Santos Government believed were major changes in approach, and decision was made to withdraw the bill in late 2017 in the expectation to reintroduce it during the last session of the previous Congress in March 2018. However, after the Congressional elections of that month and the launching of presidential campaigns for the first ballot in May the discussion of land reforms proved politically unfeasible.

After the inauguration of President Duque in early August, uncertainty has remained about the land policies that will pursue the new administration and the future of the land agencies during the four-year term. Apart from a strong ideological preference for the protection of private property rights, candidate Duque seemed supportive of the core of the Final Peace Accord in connection with rural land. If previous law/policymaking processes may illuminate the future, the new Government of Colombia will have to be remain open to dialogue with the various stakeholders on rural land to develop and implement an agenda for reform and avoid any attempt to steamroll legislation in Congress. However, the timing for the reform proposals may be short-lived; beyond the first year of the incoming administration where the political capital may remain strong (as it happened in 2011 with the Victims and Land Restitution Law), the chances of major reforms to be passed are slim. 
Hopefully, addressing the institutional issues pointed out in this paper will be a priority for the new administration, to provide for the right policy mix around three critical objectives (secured rights, access for vulnerable groups, and land productivity) to be implemented. A few changes may require legislation (such as merging or abolishing institutions) but the majority depend on administrative decisions (for instance, information management) that can be taken under the current legal/regulatory framework. In any event, the law-making process should avoid generating new mandates for already overstretched institutions while the critical issues of inter-institutional coordination and land information management remain unaddressed.

\section{Bibliography}

\section{Books}

LÓPEZ SIABATO, N., MONTEALEGRE GÓNGORA, C., QUINTERO RAMÍREZ, M. C., \& LOZANO ARDILA, M. C., Percepción de las implicaciones psicológicas y sociales del proceso de restitución de tierras en Colombia. (Bogotá, 2013).

MACHADO, A. J., \& VIVAS, J. A., Ensayos para la historia de la politica de tierras en Colombia. de la Colonia a la creación del Frente Nacional (Universidad Nacional de Colombia, Bogotá, 2009).

SAÑUDO PAZOS, M. F., Tierra y género. dilemas y obstáculos en los procesos de negociación de la politica de tierras en Colombia (Editorial Pontificia Universidad Javeriana, Bogotá, 2015).

ZULETA, E.., La tierra en Colombia (La Oveja Negra, Medellín, 1976).

\section{Journals}

ACEVEDO, M., \& SERRANO, R., Transformaciones generadas al régimen de propiedad privada y de posesión de inmuebles en la Ley de Victimas y Restitución de Tierras en Colombia, Eleuthera, 141 (2015). https://doi.org /10.17151/eleu.2015.12.8.

GONZÁLEZ, J \& HENAO, J., Una nueva forma de concentración de la tierra en Colombia: la Ley 1448 de 2011 / A New Form of Concentration of Land in Colombia: Law 1448 of 2011, Ecos De Economía, 34, 75 (2012).

GUZMÁN, A., \& BARÓN, N., Dimensión constitucional y mecanismos de la Acción de Restitución de tierras en Colombia, Revista de Derecho, 48, 143-170 (2018).

JARAMILLO, D., VARGAS, G., \& ARANGO, P. R., La justicia en una pendiente resbaladiza: los errores lógicos de la oposición a las leyes de reparación de víctimas y restitución de tierras en Colombia, Revista Juridicas, 10, 2, 87-94 (2013).

MARTÍNEZ, C. M., \& PÉREZ, A. C., La Restitución De Tierras En Colombia Expectativas y Retos. Prolegómenos Derechos Y Valores, 15, 29, 111-127 (2012).

MEERTENS, D., Gender and Land Justice in Colombia: Challenges for the Post-Peace Accords Era / Justicia de género y tierras en Colombia: desafios para la era del 'pos-acuerdo'. European Review of Latin American And Caribbean Studies, 102, 89 (2016).

MONTOYA, C. \& VALLEJO, M., Encuadres Retórico-Políticos En La Ley De Víctimas Y Restitución De Tierras En Colombia / Political Rhetoric Framing in the Law of Victims and Land Restitution In Colombia, Análisis Politico, 84, 23 (2015). https://doi.org/10.15446/anpol.v28n84.54637

MORA, G., La disputa por la tierra en Colombia sobre los resguardos: conceptos, ángulos analíticos y puntos de vista / The Dispute for Land in Colombia over the Resguardos: Concepts, Analytical Angles and Standpoints. Papel Politico, 1, 57 (2016). https://doi.org/10.11144/Javeriana.papo21-1.dlcr

POYATOS, M., ALEXANDRA, A., GUARÍN, A., VICTORIA, L., \& JENNI, L.., El Geoportal para la Administración de Tierras en Colombia, Revista Cartográfica, 95, 151-167 (2017).

SAFFON. M., The Project of Land Restitution in Colombia: An Illustration of the Civilizing Force of Hypocrisy? El proyecto de restitución de tierras en Colombia: cilustración de la fuerza civilizadora de la hipocresía? Estudios Socio-Jurídicos, (2), 109 (2010). 
SANABRIA, L. P., Innovaciones de las ciencias sociales en la ejecución de la política pública de restitución de tierras en Colombia. Revista Trabajo Social, (17), 13-26 (2015).

SERRANO. R., \& ACEVEDO. M., Reflexiones en torno a la aplicación de la Ley 1448 de 2011 y la restitución de tierras en Colombia / Reflections around the law 1448, 2011 and land restitution in Colombia, Revista de la Facultad de Derecho y Ciencias Politicas, 119, 533 (2013).

THOMSON, F., Restitución de tierras en Colombia: ¿por qué las solicitudes son tan pocas?, Revista Migraciones Forzadas, 56, 35-36 (2017).

UPRIMNY, M. \& SANCHEZ, N., Los dilemas de la restitución de tierras en Colombia / Dilemmas in Regards to the Restitution of Lands in Colombia / Os dilemas da restituição de terra na Colômbia. Estudios Socio-Jurídicos, 2, 305 (2010).

Uribe Lopez, M., El veto de las elites rurales a la redistribucion de la tierra en Colombia / Rural Elites' Veto of Land Reform in Colombia), Revista de Economia Institucional, 11, 21, 93-106 (2009).

VARGAS-REINA, J. Alejandro Reyes Posada. Guerreros y Campesinos. El Despojo de la Tierra en Colombia, Revista Estudios Socio-Jurídicos, 2, 381 (2010).

\section{Official national and international sources}

ALTO COMISIONADO PARA LA PAZ, Acuerdo Final Para La Terminación Del Conflicto Y La Construcción De Una Paz Estable Y Duradera. Recuperado de: http://www.altocomisionadoparalapaz.gov.co/procesos-y-conve rsaciones/Documentos\%20compartidos/24-11-2016NuevoAcuerdoFinal.pdf

BANCO MUNDIAL, Colombia. Measuring Business Regulation. http://www.doingbusiness.org/data/exploreecono mies/colombia\# registering-property

BANCO MUNDIAL, Development Indicators. DataBank. http://databank.worldbank.org/data/reports.aspx?sourc $\mathrm{e}=2 \&$ country $=\mathrm{COL}$

BANCO MUNDIAL, Mejora de la Gobernanza de la Tierra en Colombia: Implementación del Marco de Evaluación de la Gobernanza de la Tierra (2013). http://siteresources.worldbank.org/INTLGA/Resources/Colombia_Fi nal_Report.pdf

DEPARTAMENTO ADMINISTRATIVO NACIONAL DE ESTADÍSTICA, DANE, Pobreza Monetaria y Multidimensional en Colombia 2017 (2017). https://www.dane.gov.co/index.php/estadisticas-por-tema/pobre za-y-condiciones-de-vida/pobreza-y-desigualdad/pobreza-monetaria-y-multidimensional-en-colombia-2017\# pobreza-monetaria-por-departamentos-2017

INSTITUTO GEOGRÁFICO AGUSTÍN CODAZZI; CORPORACIÓN COLOMBIANA DE INVESTIGACIÓN AGROPECUARIA, Zonificación de los conflictos de uso de las tierras en Colombia (2002). http://observatorio.unillanos.edu.co/portal/archivos/97conf_uso_tierra_(Cap\%202Cobertura).pdf

\section{Thesis}

SAÑUDO PAZOS, M. F., Representaciones de género y acceso a la propiedad de la tierra en Colombia (2014).

\section{Other sources}

THE ECONOMIST, Democracy Index (2015), Recuperado de: http://www.eiu.com/Handlers/WhitepaperHandl er.ashx?fi=EIU-Democracy-Index-2015.pdf\&mode=wp\&campaignid=DemocracyIndex 2015

MORENO, M., Gobierno creará ente único que maneje las tierras del país, Portafolio (2015, 15 de julio). https://ww w.portafolio.co/economia/finanzas/gobierno-creara-ente-unico-maneje-tierras-pais-31338

https://formularios.dane.gov.co/Anda_4_1/index.php/catalog/356/export

https://colaboracion.dnp.gov.co/CDT/Conpes/Econ\%C3\%B3micos/3859.pdf 
https://colaboracion.dnp.gov.co/CDT/PND/PND\%202014-2018\%20Tomo\%201\%20internet.pdf https://colaboracion.dnp.gov.co/CDT/Agriculturapecuarioforestal\%20y\%20pesca/El\%20CAMPO\%20COLOM BIANO\%20UN\%20CAMINIO\%20HACIA\%20EL\%20BIENESTAR\%20Y\%20LA\%20PAZ\%20MTC.pdf

\section{Notes}

1 http://databank.worldbank.org/data/reports.aspx?source=2\&country=COL

2 https://www.dane.gov.co/index.php/estadisticas-por-tema/pobreza-y-condiciones-de-vida/pobreza-y-desigualdad/po breza-monetaria-y-multidimensional-en-colombia-2017\#pobreza-monetaria-por-departamentos-2017

3 https://formularios.dane.gov.co/Anda_4_1/index.php/catalog/356/export

4 MACHADO CARTAGENA, A. J., \& VIVAS, J. A. Ensayos para la historia de la política de tierras en Colombia. de la Colonia a la creación del Frente Nacional, (Universidad Nacional de Colombia, Bogotá, 2009).

5 URIBE LÓPEZ, M. El veto de las elites rurales a la redistribucion de la tierra en Colombia / Rural Elites' Veto of Land Reform in Colombia, Revista De Economia Institucional, 11, 21, 93-106 (2009).

6 ZULETA, E. La tierra en Colombia (la Oveja Negra, Medellin,1976).

7 VARGAS-REINA, J. Guerreros y Campesinos. El Despojo de la Tierra en Colombia, Revista Estudios Socio-Juridicos, 2, $381(2010)$.

8 http://www.eiu.com/Handlers/WhitepaperHandler.ashx?fi=EIU-Democracy-Index-2015.pdf\&mode=wp\&campai gnid=DemocracyIndex2015

9 http://www.altocomisionadoparalapaz.gov.co/procesos-y-conversaciones/Documentos\%20compartidos/24-11-2016 NuevoAcuerdoFinal.pdf

10 Municipalities with no cadaster are mostly located in the Departments of Chocó, Amazonas, Vaupés, Guainía y Nariño. These regions include $81 \%$ of the indigenous territories (Resguardos Indigenas), collective property territories, afrodescendants, and many of the protected areas of the Country.

11 This may partly explain why around 28 percent of the territory has never been surveyed: most of these plots have little or no tax potential.

12 https://colaboracion.dnp.gov.co/CDT/PND/PND\%202014-2018\%20Tomo\%201\%20internet.pdf

13 https://colaboracion.dnp.gov.co/CDT/Agriculturapecuarioforestal\%20y\%20pesca/El\%20CAMPO\%20COLOMBI ANO\%20UN\%20CAMINIO\%20HACIA\%20EL\%20BIENESTAR\%20Y\%20LA\%20PAZ\%20MTC.pdf

14 The rural development plans of some municipalities should help to make visible to the local governments the needs and priorities of rural communities that were not captured in other planning instruments such as the National/ Departmental/Municipal Development Plans or the Territorial Management Plans (Planes de Ordenamiento Territorial - POTs). A hybrid methodology for Rural Development Plans with a Territorial Focus (PDTs) has been developed by Javeriana University.

15 https://colaboracion.dnp.gov.co/CDT/Conpes/Econ\%C3\%B3micos/3859.pdf

16 GERMÁN ANDRÉS, M. V. La disputa por la tierra en Colombia sobre los resguardos: conceptos, ángulos analíticos y puntos de vista / The Dispute for Land in Colombia over the Resguardos: Concepts, Analytical Angles and Standpoints. Papel Politico, 1, 57 (2016). https://doi.org/10.11144/Javeriana.papo21-1.dlcr

17 http://siteresources.worldbank.org/INTLGA/Resources/Colombia_Final_Report.pdf

18 https://www.supernotariado.gov.co/PortalSNR/faces/oracle/webcenter/portalapp/pages/home.jspx

19 http://www.igac.gov.co/igac

20 http://www.doingbusiness.org/data/exploreeconomies/colombia\# registering-property

21 http://www.agenciadetierras.gov.co/

22 http://www.adr.gov.co/

23 http://www.renovacionterritorio.gov.co/

24 Unfortunately, the initial announcement about a "single rural land authority" that would unify the dispersed institutional framework of the sector did not materialize. See http://www.portafolio.co/economia/finanzas/gobierno-creara-enteunico-maneje-tierras-pais-31338

25 https://www.minagricultura.gov.co/Paginas/default.aspx

26 Recent literature on land restitution is abundant while other topics such as formalization have not received similar attention. Catalina, M. L., \& Maryluz, V. M. (2015). ENCUADRES RETÓRICO-POLÍTICOS EN LA LEY DE VÍCTIMAS Y RESTITUCIÓN DE TIERRAS EN COLOMBIA / POLITICAL RHETORIC FRAMING IN THE LAW OF VICTIMS AND LAND RESTITUTION IN COLOMBIA. Análisis Politico, (84), 23. doi:10.15446/anpol.v28n84.54637. Guzmán-Rincón, A., \& Barón-Rocha, N. (2018). Dimensión constitucional y mecanismos de la Acción de Restitución de tierras en Colombia. Revista De Derecho, (48), 143-170. Rocío, S. G., \& 
Milena, A. P. (2013). Reflexiones en torno a la aplicación de la Ley 1448 de 2011 y la restitución de tierras en Colombia / Réflexions autour de la mise en application de la loi 1448, 2011 et la restitution des terres en Colombie / Reflections around the law 1448, 2011 and land restitution in Colombia / Reflexões em torno à implementação da lei 1448 de 2011 e a restituição de terras na Colômbia. Revista De La Facultad De Derecho Y Ciencias Políticas, (119), 533. Jhon Jair, G. P., \& Juan Pablo, H. G. (2012). Una nueva forma de concentración de la tierra en Colombia: la Ley 1448 de $2011 /$ A new form of concentration of land in Colombia: Law 1448 of 2011. Ecos De Economía, (34), 75. Acevedo Prada, M., \& Serrano Gomez, R. (2015). TRANSFORMACIONES GENERADAS AL REGIMEN DE PROPIEDAD PRIVADA Y DE POSESION DE INMUEBLES EN LA LEY DE VICTIMAS Y RESTITUCION DE TIERRAS EN COLOMBIA. Eleuthera, 141. doi:10.17151/eleu.2015.12.8. Rodrigo, U., \& Nelson Camilo, S. (2010). Los dilemas de la restitución de tierras en Colombia / Dilemmas in Regards to the Restitution of Lands in Colombia / Os dilemas da restituição de terra na Colômbia. Estudios Socio-Jurídicos, (2), 305. Maria Paula, S. (2010). The Project of Land Restitution in Colombia: An Illustration of the Civilizing Force of Hypocrisy? / O projeto de restituição de terras na Colômbia: ilustração da força civilizadora da hipocrisia? / El proyecto de restitución de tierras en Colombia: ¿ilustración de la fuerza civilizadora de la hipocresía?. Estudios Socio-Jurídicos, (2), 109. MARTÍNEZ SANABRIA, C. M., \& PÉREZ FORERO, A. C. La restitución de tierras en Colombia expectativas y retos, Prolegómenos Derechos y Valores, $15,29,111-127$ (2012). Resbaladiza: Los errores lógicos de la oposición a las leyes de reparación de víctimas y restitución de tierras en Colombia, Revista Juridicas, 10,2, 87-94 (2013).

A municipal office that provides free legal assistance services to citizens and has specific programs for victims. http://w ww.fenalper.org/proyectos-y-o-convenios/victimas

37 Most of the information for the following sections was validated by the author through in-depth interviews with representatives and users of the rural land sector institutions conducted between March and April 2017 within the framework of the mid-term evaluation of the USAID-financed Land and Rural Development Program (LRDP).

38 http://siteresources.worldbank.org/INTLGA/Resources/Colombia_Final_Report.pdf

39 SANABRIA TORRE, L. P. Innovaciones de las ciencias sociales en la ejecución de la política pública de restitución de tierras en Colombia, Revista Trabajo Social, (17), 13-26 (2015). LÓPEZ SIABATO, N., MONTEALEGRE GÓNGORA, C., QUINTERO RAMÍREZ, M. C., \& LOZANO ARDILA, M. C. Percepción de las implicaciones psicológicas y sociales del proceso de restitución de tierras en Colombia. (Bogotá, 2013).

40 THOMSON, F. Restitución de tierras en Colombia: ¿por qué las solicitudes son tan pocas?, Revista Migraciones Forzadas, 56, 35-36 (2017).

41 Art. 72, 97 and 98, Law No. 1448 of 2011.

42 More seriously, the combination of administrative/judicial processes may be the result of a deliberate intent to leave land issues pending sine die, as the previous experiences with court rulings on land matters in Colombia has shown they may take years or even decades.

43 A separate discussion would deserve the Colombian preference for a "legal" instrument that is more prescriptive and limits the powers of administrative authorities instead of a "policy" instrument which must necessarily provide them with some discretional powers.

44 Ovejas (Sucre Department) and Santander de Quilichao (Cauca Department).

45 Approximately 29,000 families in Colombia could also benefit from this type of formalization process.

46 MEERTENS, D. Gender and land justice in Colombia: challenges for the post-peace accords era/Justicia de genero y tierras en Colombia: desafios para la era del 'pos-acuerdo', European Review of Latin American and Caribbean Studies, 102, 89 (2016). SAÑUDO PAZOS, M. F. Representaciones de género y acceso a la propiedad de la tierra en Colombia (2014). SAÑUDO PAZOS, M. F. Tierra y género. dilemas y obstáculos en los procesos de negociación de la política de tierras en Colombia (Editorial Pontificia Universidad Javeriana, Bogotá, 2015).

47 For example, the Special Land Courts started to receive digital files from URT but preferred to continue with a manual system. 
49 Information on certain non-marketable lands, such as national parks and protected areas, is more reliable but uncertainties remain on some boundaries or cases of illegal squatting.

50 POYATOS BENADERO, M., ALEXANDRA MORALES, A., GUARÍN, A., VICTORIA BARÓN, L., \& JENNI, L. El Geoportal para la Administración de Tierras en Colombia, Revista Cartográfica, 95, 151-167 (2017).

51 For instance, in early 2017 SNR awarded a USD14 million contract for the implementation of a new Registry Integrated Information System (SIIR) designed to improve the quality of the services for the final user while streamlining the internal review processes. It was not clear how SIIR will be connected with the Land Node, and whether funding was included in the contract to that end. As of March 2018, there was a high risk that contract would have to be terminated because of non-performance of the supplier.

52 CONPES Document No. 3859 of 2016, pg. 82.

53 CONPES Document No. 3859 of 2016, pg. 56.

54 Zonificación de los conflictos de uso de las tierras en Colombia. [Recurso electrónico]. (2002). Bogotá Instituto Geográfico Agustín Codazzi Corporación Colombiana de Investigación Agropecuaria c2002.

55 http://www.posconflicto.gov.co/Paginas/posconflicto.aspx

* Research article.

\section{Licencia Creative Commons CC BY 4.0}

To cite this article: VARELA, DAVID FERNANDO, Rural Land Reforms in Colombia. Policy and Institutional Challenges for the new Administration, 138 Vniversitas (2019). https://doi.org/10.11144/Jav eriana.vj138.rlrc 